DOI: $10.17516 / 1997-1370-0585$

УДК 339.5

\title{
Assessing Competitiveness of Forest Industry: Theoretical and Empirical Aspects
}

\author{
Roman V. Gordeev* \\ Siberian Federal University \\ Krasnoyarsk, Russian Federation \\ Institute of Economics and Industrial Engineering of the $S B R A S$ \\ Novosibirsk, Russian Federation
}

Received 10.03.2020, received in revised form 15.03.2020, accepted 20.03.2020

\begin{abstract}
Numerous studies are dedicated to the competitiveness assessment of countries, regions and industries. However, it is not easy to choose the methodology to assess the competitiveness of forest products. The main difficulties arise even at the stage of defining the term "competitiveness", selecting the criteria for its achievement and choosing the measure suitable for its evaluation. This article analyzes the theoretical foundations of competitiveness in terms of two main approaches: comparative and competitive advantages. The main novel result of this work is a comprehensive review of empirical competitiveness assessments as regards the forest industry. Several methods have been identified as the most popular means to explore forest products' competitiveness. One of the most convenient approaches to estimate competitiveness at the national and regional level is to calculate the comparative advantage revealed. The last section of the article covers the benefits and disadvantages of this approach.
\end{abstract}

Keywords: competitiveness, comparative advantage, competitive advantage, trade theory, forestry, timber industry.

The reported study was funded by the Russian Foundation for Basic Research (the research project No. 18-010-01175).

Research area: economics and national economy management.

Citation: Gordeev, R.V. (2020). Assessing competitiveness of forest industry: theoretical and empirical aspects. J. Sib. Fed. Univ. Humanit. Soc. Sci., 13(4), 507-516. DOI: 10.17516/1997-1370-0585.

\footnotetext{
(C) Siberian Federal University. All rights reserved

* Corresponding author E-mail address: rgordeev@sfu-kras.ru ORCID: 0000-0002-2769-3914
} 


\section{Introduction}

The use of the term "competitiveness" has become widespread in the economic literature, business communication and even public discourse. Capobianco-Uriarte et al. (2019) found that the number of articles on competitiveness published annually increased from 15 in 1983 to 146 in 2017. However, there is no universal definition or coordinated estimation procedure for competitiveness.

Durand and Giorno (1987) argued that the ideal tool for measuring competitiveness should meet three criteria: represent all goods involved in competition, cover all the markets and use internationally comparable data. But in practice, the researcher often faces various constraints. Therefore, under different conditions, the choice of evaluation approach depends on the object of the study, the set of available statistics and the purpose of the analysis. The analysis of forest product competitiveness is no exception within this framework.

Forestry is the kind of economic activity that strongly affects Earth's ecosystems. It is closely connected with the different aspects of hydrological cycle (Bartík et al., 2018), climate change (Pyzhev, Vaganov, 2019; Chugunkova, 2019) and changes in fauna (Mezei et al., 2017; Ivantsova et al., 2019). Therefore, the study of forest sector competitiveness is an important and relevant task.

There are many articles that address the competitiveness of the forest sector. However, a large part of them is devoted to identifying factors of competitiveness and opportunities to improve it. A direct empirical assessment of forest sector competitiveness at the national or regional level has received much less attention in the literature. This article presents an attempt to summarize and analyze the studies on forest sector competitiveness assessment.

\section{Theoretical framework of competitiveness}

Initially, the concept of competitiveness was associated primarily with the Porter's theory of competitive advantages (Porter, 1990) and was perceived by representatives of academia with skepticism. For example, Krugman (1994) actively opposed the transfer of this idea from the firms to the national economies, calling the "obsession with competitiveness" meaningless, erroneous and dangerous. However, Cho and Moon (2000) show that competitiveness theory is rooted in classical trade theories. Therefore it is necessary to discuss two main approaches to competitiveness assessment: using methodology of international trade theories and building a multi-criteria model within the framework of the Porter's theory.

\section{Trade theories \\ and comparative advantage}

The starting point for the development of trade theories was mercantilism. Mercantilists studied the movement of money and goods between countries, encouraged government intervention in international trade and supported protectionism.

Smith in "The Wealth of Nations" (1776) criticized mercantilism and supported the idea of free trade. He claimed that if countries specialized in trade according to their natural absolute advantages, all nations would benefit. According to Smith, the country shall specialize in exporting goods in producing which it spends less resource than other nations and has to import products that are produced by other countries at lower costs.

Ricardo (1917) developed this idea and argued that nations without absolute advantages can also benefit from international trade if they have a comparative advantage over other countries in producing certain products. It was the concept of Ricardian comparative advantage that laid the foundation for the development of subsequent trade theories: The Heckscher-Ohlin model, New trade theory and "New" New Trade Theory.

Classical trade theories were mainly criticized for the need to expand the model by increasing the number of factors of production. At the beginning of the $20^{\text {th }}$ century, a two-factor model was formulated by Heckscher and Ohlin within the framework of neoclassical economic theory. According to the Heckscher-Ohlin theorem, the country exports capital-intensive goods if it has a relative abundance in capital or the labour-intensive products if it is labour-abundant (Ohlin, 1933). In other words, 
different proportions of factors of production in countries are the basis of comparative advantage and cause the existence of international trade.

However, the Heckscher-Ohlin model could not explain several issues. For instance, why developed economies with similar factor proportions trade with each other (Volchkova, 2009). In addition, it performed poorly in econometric studies. One of the most wellknown cases was Leontief paradox (1953).

To explain the contradictions accumulated by classical theories of international trade, Krugman (1980) developed the New Trade Theory using the toolkit of modelling monopolistic competition developed by Dixit and Stiglitz (1977). This theory is based on completely different assumptions: heterogeneity of goods, imperfect competition and increasing returns to scale. According to the New Trade Theory, the basis of comparative advantage is the market size: supplying products to a large market allows reducing production costs through economies of scale. Another important difference from the Heckscher-Ohlin model is that New Trade Theory focuses on competition among firms, not nations.

In the early 2000s, Melitz (2003), Antras and Helpman (2004) have formed a new direction in the study of international trade, called the "New" New Theory of Trade. The main idea is that the productivity of firms, as well as the market size, are the main determinants of the comparative advantages. Marginal costs vary from company to company, and as a result of increasing competition, many firms have to leave the market, thus, only the most efficient firms can successfully integrate into world trade (Wagner, 2007).

\section{Competitive advantage}

Porter has integrated in his theory some ideas from international trade theory and world business practice (Porter, 1990). He believed that national prosperity is not inherited, but created. While comparative advantages based on factors of production are stable, competitive advantages are dynamic and based on innovations and human capital development. At the same time, a decisive role in increasing com- petitiveness is played by productivity, which depends on the efficiency of production, quality and other characteristics of manufactured goods.

Based on a study of the reasons for competitive success in ten leading trading countries, Porter defines his Diamond Model of national advantage consisting of four determinants:

1. Factor conditions. Porter shares the classic view of the influence of production factors on competitive advantages. However, to enlarge the array of traditional factors (labour, land, capital) he adds some new ones, which are created, not inherited. They are adapted to a specific industry and include, for instance, the scientific and information potential of the state, the state of transport and communication, the health care system and the provision of housing.

2. Demand conditions, according to Porter, play a huge role in improving product competitiveness. In assessing the conditions of domestic demand it is necessary to take into account the characteristics of market capacity, the dynamics of its development, consumer demand, etc.

3. Presence of related and supporting industries is another crucial factor in developing competitive advantage. For any company it is extremely important to have the necessary equipment, close ties with suppliers, commercial and financial structures.

4. Strategy, structure and rivalry. High competition in the domestic market increases the chances of firms to successfully claim a significant share in the world market (Porter, 1990).

Subsequent empirical studies have shown that the Diamond model can be supplemented by other factors, including multinational activity and government. These ideas were developed as the Nine-Factor Model (Cho, 1994) and the Generalized Double Diamond Model (Moon et al., 1998).

Here there were considered the main theoretical approaches to defining and assessing the competitiveness. The next section will cover the world experience of empirical competitiveness assessments as regards the forest industry. 


\section{Empirical competitiveness estimations of forest industry}

Dieter and Englert (2007) assessed the level of competitiveness of the German timber industry in the world market. This research is devoted to the study of the main trends on the world market of timber industry products in the period 1993-2002. The authors classify all forest products into three groups according to the processing level (raw wood, semi-finished and finished wood products) and two sectors (wood and paper). Using revealed comparative advantage (RCA) indexes (Balassa, 1965; Aquino, 1999), they explored the nature of Germany's international specialization in wood products trade and analyzed the dynamics of competitiveness of 21 major exporters in the global timber market. In addition, the Constant Market Share analysis (Milana, 1988) was used to explain export growth by four effects: world growth, commodity-composition, market-distribution and competitiveness. This approach allowed the authors to establish the positive correlation between the export growth rate and the country's competitiveness level.

Daigneault et al. (2008) analyzed the competitiveness of the US timber sector depending on different exchange rate policies. They used a dynamic global timber market model (Sedjo, Lyon, 1990; Sohngen et al., 1999) that includes optimal managing investments, timberland area and age class distributions of forests. The results show that the level of competitiveness of the US forest industry is sensitive both to domestic policies to maintain a relatively high dollar exchange rate and the depreciation of South American developing countries' currencies against the US dollar.

The analysis of global competitiveness of Chinese furniture products is carried out in the article by Han et al. (2009). The Grubel and Lloyd index (1975), Balassa index and the Trade Competitiveness Index (Greenaway, Milner, 1993) were chosen as the main competitiveness indicators for the study. The purpose of the study was to assess the current level of competitiveness of the Chinese furniture industry. It was found that during the period under review, from 1993 to 2007, China went from comparative disadvantage to a relatively high advantage in furniture trade, gaining a strong position in the world markets for these products. The competitiveness analysis has shown that developed countries still have the largest share in the world furniture market, but over the period under review, they are gradually losing their competitiveness in favour of the rapidly developing countries of Southeast Asia, Eastern Europe and Latin America.

Kovalčík (2011) explored profitability and competitiveness of forest industry in 18 European countries. This study uses several indicators of competitiveness such as: output of forestry, GDP of forestry, contribution of forestry to GDP, gross value added, net value added and entrepreneurial income. All of them measured in two dimensions: per hectare of forest and per employee. The results of the comparative analysis conducted for each of the indicators show that competitiveness is strongly influenced by the state of economy (developed economy or economy in transition) and the type of region according to the author's classification. However, while indicators per employee calculated for developed countries are 5-10 times higher than for countries in transition, the difference is lower per hectare, which can be explained by the insufficient quality of statistical data used for per capita indicators.

Karpuk (2011) conducted the study of Ukrainian wood products concerning foreign trade. The author analyzed the foreign trade balance and used Grubel and Lloyd and Balassa indices to assess the competitiveness of forest products in Ukraine and compare the volume of its foreign trade with major trading partners, in particular, with the EU countries. Besides, the author provides the results of the the SWOT analysis of foreign economic activity of Ukrainian enterprises of forest industry and offers a number of measures to improve the efficiency of foreign trade in Ukrainian forest products.

A study by Bojnec and Fertő (2014) reveals the problem of forest industry competitiveness in relation to the so-called "new" EU member states that joined the EU in 2004 and 2007. The main objective of the study was to find out to what extent the trade flows of the countries under consideration have changed 
since EU accession. As a main competitiveness measure these authors chose revealed trade advantage (RTA) index, proposed by Vollrath (1991). They also calculated the duration of revealed trade advantage using methodology of survival analysis (Cleves et al., 2004). The results show that all "new" EU member states, except Cyprus, experienced comparative disadvantages in exporting their goods to the EU market. At the same time, it is noted that for most countries considered, products with high added value play a key role in the supply chains of the forest industry.

Parobek et al. (2016) analyzed the competitiveness of Slovakian wood and semi-finished wood products. Using modified Balassa index and comparative price level index the authors found that the abundance of forest resources and competitive prices determine the comparative advantage in industrial coniferous roundwood trade for Slovakia.

Vokhmyanin (2017) used the integral indicator to assess competitiveness of the Russian forest sector on regional level. It contains several indices that describe the state of the forest industry, including production factors, regional investment activity, presence of related industries, export volumes, etc. The methodology was applied to ten regions of the Northwestern Federal District. As a result, the Arkhangelsk Oblast and the Republic of Karelia were recognized as the leaders of the industry, and the lowest level of competitiveness was found for the Murmansk and Pskov Oblasts. The best dynamics of forestry development were demonstrated by the Vologda Oblast, which is explained by the renewal of fixed assets, increase in the volume of investments, improvement in the financial condition of the regional forest industry enterprises.

Rossato et al. (2018) studied wood pulp competitiveness in 6 countries: USA, Brazil, Canada, Sweden, Finland and China. For this purpose, the authors calculated several indicators of competitiveness: Balassa index, symmetric version of RCA (Dalum et al., 1998) and trade balance index (Lafay, 1990). The results showed that all countries except China have comparative advantages in wood pulp trade. The pulp industry was also found to have significant positive effects on the export economies of Brazil, Finland, Canada and Sweden, as well as moderate positive effects in the USA.

In the paper (Gordeev, Pyzhev, 2015) we studied competitiveness on national level using Balassa and Aquino indices. We also used Grubel and Lloyd index for a more thorough study of Russian intra-industry trade. However, it would not be quite correct to assess comparative advantages only at the country level. Geographical factors also have a great influence on institutional, social and economic aspects of development of Russian regions (Zubarevich, 2015; Shida, 2019). This is also true for the timber industry, as Russian regions are very heterogeneous in terms of resource endowment, proximity to markets, etc. The concept of comparative advantage can also be applied on regional level. Such studies have been conducted to analyze the competitiveness of industries in a number of countries, including Italy (Benedictis, 2005), USA (Clark et al., 2007), Brazil (Feistel, Hidalgo, 2010), China (Sawyer et al., 2017). Thus, we also assessed competitiveness at the regional level (Gordeev et al., 2018). The results show that the specialization of the Russian trade is determined by the resource abundance and low efficiency of the state forest policy. We also classified Russian regions into four groups by the number of forest products with comparative advantage in trade.

Hence, it can be concluded that the following approaches are generally used to conduct empirical studies on forest industry competitiveness (Table 1):

- various revealed comparative advantage indexes;

- estimation of price indices for timber products;

- constant market share analysis;

- optimization models;

- analysis of different sectoral indicators.

\section{Discussion}

One of the most popular approaches to assess competitiveness is to identify comparative advantages using different indices. With regard to the task of assessing competitiveness of Rus- 
Table 1. Studies on competitiveness assessment of forest products

\begin{tabular}{|c|c|c|}
\hline Authors & $\begin{array}{c}\text { Level } \\
\text { of competitiveness }\end{array}$ & Methods \\
\hline Dieter, Englert, 2007 & National & $\begin{array}{l}\text { Revealed comparative advantage indices (Balassa index, Aqui- } \\
\text { no index), the Constant Market Share analysis }\end{array}$ \\
\hline Daigneault et al., 2008 & National & Dynamic global timber market model \\
\hline Han et al., 2009 & National & $\begin{array}{l}\text { The Grubel and Lloyd index, Balassa index, the Trade Com- } \\
\text { petitiveness Index }\end{array}$ \\
\hline Kovalčík, 2011 & National & $\begin{array}{l}\text { Analysis of several indicators (Output of forestry, GDP of for- } \\
\text { estry, contribution of forestry to GDP, gross value added, net } \\
\text { value added and entrepreneurial income) }\end{array}$ \\
\hline Karpuk, 2011 & National & $\begin{array}{l}\text { Revealed comparative advantage (Balassa index) and the } \\
\text { Grubel and Lloyd index }\end{array}$ \\
\hline Bojnec, Fertő, 2014 & National & Revealed trade advantage index, survival analysis \\
\hline Parobek et al., 2016 & National & $\begin{array}{l}\text { Revealed comparative advantage index (modified Balassa in- } \\
\text { dex), comparative price level index }\end{array}$ \\
\hline Vokhmyanin, 2017 & Regional & $\begin{array}{l}\text { Integral assessment, including a number of indicators charac- } \\
\text { terizing production, foreign trade, investment climate, etc. in } \\
\text { the forest industry sector }\end{array}$ \\
\hline Rossato et al., 2018 & National & $\begin{array}{l}\text { Revealed comparative advantage indexes (Balassa index, } \\
\text { RSCA, TBI) }\end{array}$ \\
\hline $\begin{array}{l}\text { Gordeev, Pyzhev, 2015; } \\
\text { Gordeev et al., } 2018\end{array}$ & National, regional & $\begin{array}{l}\text { Revealed comparative advantage indexes (Balassa index, } \\
\text { Aquino index, RTA), the Grubel and Lloyd index }\end{array}$ \\
\hline
\end{tabular}

sian forest industry, this approach also seems to be the most convenient. In fact, it has several important advantages over other alternatives.

1. Consistency with theoretical notions of competitiveness. The concept of revealed comparative advantages was developed by B. Balassa (1965) in accordance with the Ricardo's theory of comparative advantages and the Heckscher-Ohlin model. The analysis is based on an ex-post assessment of competitiveness by calculating the share of a particular commodity in the export of the certain country compared to other countries. The above review shows that there are many different ways to measure revealed comparative advantages in trade. Comprehensive comparison of different RCA indicators was given by Gnidchenko and Salnikov (2015).

2. Availability of data. The lack or absence of the necessary statistics is a serious limitation for many studies. Calculating revealed comparative advantages requires only trade statistics, which is available for Russia and is very detailed. With respect to the for- est sector, this allows: (1) to conduct analysis not only at the national level but also at the regional level; (2) to calculate comparative advantages not only by product groups but also by certain products.

3. Simplicity of calculation. Even if the necessary data were available, the approaches of assessing competitiveness mentioned above would have different labour intensity. And with limited access to data it seems difficult to use alternative approaches to assess competitiveness at the regional level or for a specific forest product. Calculating revealed comparative advantages appears to be the simplest way to assess competitiveness and its results are easy to interpret. Besides, this approach does not require additional use of optimization modelling or multi-criteria models such as the Diamond Model.

However, it should also be noted that the concept of revealed comparative advantage has some limitations.

1. New Trade Theory and "New" New Trade Theory indicate that the subjects of com- 
petition are corporations, not countries, regions or industries. However, firm statistics are still largely unavailable, making it impossible to build complete models under these theories.

2. Perhaps the main shortcoming of revealed comparative advantages is that interregional trade flows within a country remain unaccounted for. Therefore, it is possible to evaluate competitiveness of forest products only on the global market and not on the domestic one.

3. The estimates may be biased due to the fact that the country (or region) in which the product is produced is not always the final exporter as well. This problem has been widely discussed in literature, but there seems to be no way to offset this effect beyond the use of other data sources (Coughlin, Mandelbaum, 1991; Erickson, Hayward, 1991; Cronovich, Gazel, 1998). In respect to the forest sector, the problem is that current timber turnover control system does not allow for credible assurance that exported wood has been harvested in the same region.

\section{Conclusion}

This article contributes to the literature on forest sector competitiveness in several dimensions. First, theoretical approaches to assess competitiveness from the perspective of international trade theories and Porter's theory of competitive advantage were analyzed. The evolution of the competitiveness definition within these approaches was shown.

Secondly, an overview of empirical studies on competitiveness assessment with regard to forest industry was made. It was found that usually the following approaches are used in order to conduct competitiveness analysis of forest products: revealed comparative advantage indices; price indices; constant market share analysis; optimization models; various indicators of forest sector state.

Finally, it was concluded that one of the most popular measures to assess competitiveness is an approach based on the concept of revealed comparative advantage. The pros and cons of its application to assess the competitiveness of forest products were described.

\section{References}

Antràs, P., Helpman, E. (2004). Global Sourcing. In Journal of Political Economy, 112(3), 552-580. DOI: $10.1086 / 383099$

Aquino, A. (1978). Intra-industry trade and Inter-industry specialization as concurrent sources of international trade in manufactures. In Weltwirtschaftliches Archiv, 114(2), 275-296.

Balassa, B. (1965). Trade Liberalisation and "Revealed" Comparative Advantage. In Manchester School, 33(2), 99-123. DOI: 10.1111/j.1467-9957.1965.tb00050.x

Bartík, M., Holko, L., Jančo, M., Škvarenina, J., Danko, M., \& Kostka, Z. (2019). Influence of Mountain Spruce Forest Dieback on Snow Accumulation and Melt. In Journal of Hydrology and Hydromechanics, 67(1), 59-69. DOI: 10.2478/johh-2018-0022

Bojnec, Š., Fertö, I. (2014). Forestry industry trade by degree of wood processing in the enlarged European Union countries. In Forest Policy and Economics, 40, 31-39. DOI: 10.1016/j.forpol.2013.11.009

Capobianco-Uriarte, M. de las M., Casado-Belmonte, M. del P., Marín-Carrillo, G.M., \& Terán-Yépez, E. (2019). A Bibliometric Analysis of International Competitiveness (1983-2017). In Sustainability: Science Practice and Policy, 11(7), 1877. DOI: 10.3390/su11071877

Cho, D.S. (1994). A dynamic approach to international competitiveness: The case of Korea. In Journal of Far Eastern Business, 1(1), 17-36. DOI: 10.1080/13602389400000002

Cho, D.S., Moon, H.C. (2000). From Adam Smith to Michael Porter. Evolution of Competitiveness Theory. World Scientific Publishing Co. Re. Ltd., 223 p.

Chugunkova, A.V. (2019). Napravleniia adaptatzii i smiagcheniia posledstvii izmeneniia klimata dlia ekonomiki lesnogo khoziaistva Rossii [Climate change mitigation and adaptation options in the Russian forestry sector]. In Ekonomicheskii analiz: teoriia i praktika [Economic analysis: theory and practice] 18(11), 2078-2102. DOI: 10.24891/ea.18.11.2078 
Clark, D.P., Sawyer, W.C., \& Sprinkle, R.L. (2005). Revealed Comparative Advantage Indexes for Regions of the United States. In Global Economy Journal, 5(1), 1-26. DOI: 10.2202/1524-5861.1033

Cleves, M.A., Gould, W.W., \& Gutierez, R.G. (2004). An Introduction to Survival Analysis Using STATA. Stata Press, College Station, Texas, $372 \mathrm{p}$.

Coughlin, C.C., Mandelbaum, T.B. (1991). Measuring State Exports: Is There a Better Way? In Federal Reserve Bank of St. Louis Review, 73(4), 65-79.

Cronovich, R., Gazel, R. (1998). Do Exchange Rates and Foreign Incomes Matter for Exports at the State Level? In Journal of Regional Science, 38(4), 639-657. DOI: 10.1111/0022-4146.00114

Daigneault, A.J., Sohngen, B., \& Sedjo, R. (2008). Exchange rates and the competitiveness of the United States timber sector in a global economy. In Forest Policy and Economics, 10(3), 108-116. DOI: 10.1016/j.forpol.2007.07.001

Dalum, B., Laursen, K., \& Villumsen, G. (1998). Structural Change in OECD Export Specialisation Patterns: de-specialisation and "stickiness." In International Review of Applied Economics, 12(3), 423-443. DOI: $10.1080 / 02692179800000017$

De Benedictis, L. (2005). Three Decades of Italian Comparative Advantages. In The World Economy, 28(11), 1679-1709. DOI: 10.2139/ssrn.454060

Dieter, M., Englert, H. (2007). Competitiveness in the global forest industry sector: an empirical study with special emphasis on Germany. In European Journal of Forest Research, 126(3), 401-412. DOI: 10.1007/s10342-006-0159-x

Dixit, A., Stiglitz, J. (1977). Monopolistic competition and optimum product diversity. In American Economic Review, 67(3), 297-308.

Durand, M., Giorno, C. (1987). Indicators of International Competitiveness: Conceptual Aspects and Evaluation. In OECD Econ. Stud., 147-182.

Erickson, R.A., Hayward, D.J. (1991). The International Flows of Industrial Exports from U.S. Regions. In Annals of the Association of American Geographers. Association of American Geographers, 81(3), 371-390. DOI: 10.1111/j.1467-8306.1991.tb01700.x

Feistel, P., Hidalgo, A. (2010). Brazilian regions' trade in MERCOSUR: An analysis of comparative advantages. In Integration and Trade, 31(14), 81-89.

Gnidchenko, A.A., Salnikov, V.A. (2015). Net Comparative Advantage Index: Overcoming the Drawbacks of the Existing Indices. Higher School of Economics Research Paper No. WP BRP 119/EC/2015. DOI: 10.2139/ssrn.2709009

Gordeev, R.V., Pyzhev, A.I. (2015). Analiz global'noi konkurentosposobnosti rossiiskogo lesopromyshlennogo kompleksa [Analysis of the Global Competitiveness of the Russian Timber Industry]. In $E K O$, $6,109-130$.

Gordeev, R.V., Pyzhev, A.I., \& Zander, E.V. (2018). Konkurentosposobnost' lesopromyshlennykh kompleksov regionov Rossii [Competitiveness analysis of Russian regions' forest industries]. In Tomsk State University Journal of Economics, 43, 65-87. DOI: 10.17223/19988648/43/5.

Greenaway, D., Milner, C. (1993). Trade and Industrial Policy in Developing Countries. In A Manual of Policy Analysis, Part IV Evaluating Comparative Advantage. New York. The Macmillan Press, 181-208.

Grubel, H., Lloyd, P. (1975). Intra-industry Trade: The Theory and Measurement of International Trade with Differentiated Product. London: Macmillan, 205 p.

Han, X., Wen, Y., \& Kant, S. (2009). The global competitiveness of the Chinese wooden furniture industry. In Forest Policy and Economics, 11(8), 561-569. DOI: 10.1016/j.forpol.2009.07.006

Ivantsova, E.D., Pyzhev, A.I., \& Zander, E.V. (2019). Economic Consequences of Insect Pests Outbreaks in Boreal Forests: A Literature Review. In Journal of Siberian Federal University. Humanities \& Social Sciences, 12(4), 627-642. DOI: 10.17516/1997-1370-0417

Karpuk, A. (2011). Development of foreign trade of Ukraine with the wood products [Razvitie vneshnei torgovli Ukrainy drevesnoi produktciei]. In Commodities and markets, 2, 26-36.

Kovalčík, M. (2011). Profitability and competitiveness of forestry in European countries. In Journal of Forest Science, 57(9), 369-376. DOI: 10.17221/138/2010-jfs 
Krugman, P. (1980). Scale Economies, Product Differentiation, and the Pattern of Trade. In American Economic Review, 70(5), 950-959.

Krugman, P. (1994). Competitiveness: A Dangerous Obsession. In Foreign Affairs, 73(2), 28-44.

Lafay, G. (1990). The measurement of revealed comparative advantages [La measure des avantages comparatifs revéles]. In Economie Prospective Internationale, 41, $27-43$.

Leontief, W. (1953). Domestic Production and Foreign Trade; The American Capital Position Re-Examined. In Proceedings of the American Philosophical Society, 97(4), 332-349.

Melitz, M. (2003). The impact of trade on aggregate industry productivity and intra-industry reallocations. In Econometrica: Journal of the Econometric Society, 71(6), 1695-1725.

Mezei, P., Jakuš, R., Pennerstorfer, J., Havašová, M., Škvarenina, J., Ferenčík, J., Slivinský, J., Bičárová, S., Bilčík, D., Blaženec, M., \& Netherer, S. (2017). Storms, temperature maxima and the Eurasian spruce bark beetle Ips typographus - An infernal trio in Norway spruce forests of the Central European High Tatra Mountains. In Agricultural and Forest Meteorology, 242, 85-95. DOI: 10.1016/j.agrformet.2017.04.004

Milana, C. (1988). Constant-market-share analysis and index number theory. In European Journal of Political Economy, 4, 453-478. DOI: 10.1016/0176-2680(88)90011-0.

Moon, H.C., Rugman, A.M., \& Verbeke, A. (1998). A generalized double diamond approach to the international competitiveness of Korea and Singapore. In International Business Review, 7, 135-150. DOI:10.1016/s0969-5931(98)00002-x.

Ohlin, B.G. (1933). Interregional and international trade. Cambridge, Harvard University Press, 617 p.

Parobek, J., Paluš, H., Kalamárová, M., Loučanová, E., Križanová, A., \& Štofková, K.R. (2016). Comparative Analysis of Wood and Semi-Finished Wood Product Trade of Slovakia and Its Central European Trading Partners. In Drewno, 59(196), 183-194. DOI: 10.12841/wood.1644-3985.143.15

Porter, M.E. (1990). The Competitive Advantage of Nations. In Harvard Business Review, 68(2), 73-93.

Pyzhev, A.I., Vaganov, E.A. (2019). Rol' rossiiskikh lesov v realizatcii Parizhskogo klimaticheskogo soglasheniia: vozmozhnosti ili riski? [Global Climate Change Economics: The Role of Russian Forests]. In ECO, 11, 27-44. DOI: 10.30680/ECO0131-7652-2019-11-27-44

Ricardo, D. (1917). The principles of political economy \& taxation. London, J.M. Dent \& sons, ltd.; New York, E. P. Dutton \& co., 300 p.

Rossato, F.G.F.S., Susaeta, A., Adams, D.C., Hidalgo, I.G., de Araujo, T.D., \& de Queiroz, A. (2018). Comparison of revealed comparative advantage indexes with application to trade tendencies of cellulose production from planted forests in Brazil, Canada, China, Sweden, Finland and the United States. In Forest Policy and Economics, 97, 59-66. DOI: 10.1016/j.forpol.2018.09.007

Sawyer, W.C., Tochkov, K., \& Yu, W. (2017). Regional and Sectoral Patterns and Determinants of Comparative Advantage in China. In Frontiers of Economics in China, 12(1), 7-36. DOI: 10.3868/s060006-017-0002-6

Sedjo, R.A., Lyon, K.S. (1990). The Long-Term Adequacy of World Timber Supply. Resources for the Future. Washington DC, $230 \mathrm{p}$.

Shida, Y. (2019). Russian business under economic sanctions: is there evidence of regional heterogeneity? In Post-Communist Economies, 1-21. DOI: 10.1080/14631377.2019.1659567

Smith, A. (1776). An Inquiry into the Nature and Causes of the Wealth of Nations. Vol. II (1 ed.). London: W. Strahan; and T. Cadell. 588 p.

Sohngen, B., Mendelsohn, R., \& Sedjo, R. (1999). Forest management, conservation, and global timber markets. In American Journal of Agricultural Economics, 81(1), 1-13. DOI: 10.2307/1244446.

Vokhmyanin, I.A. (2017). Otzenka konkurentosposobnosti lesnykh kompleksov territorii [Assessment of Competitiveness of the Timber Complexes of the Territories]. In Problemy razvitiia territorii [Problems of Territory's Development], 2(88), 77-91.

Volchkova, N. (2009). Novaia teoriia mezhdunarodnoi torgovli i novaia ekonomicheskaia geografiia (Nobelevskaia premiia po ekonomike 2008 goda) [New Theory of International Trade and New Economic Geography (Nobel Prize in Economics 2008)]. In Voprosy Ekonomiki, 1, 68-83. DOI: 10.32609/0042-87362009-1-68-83 
Vollrath, T.L. (1991). A theoretical evaluation of alternative trade intensity measures of revealed comparative advantage. In Weltwirtschaftliches Archiv, 127(2), 265-280. DOI: 10.1007/bf02707986

Wagner, J. (2007). Exports and Productivity: A Survey of the Evidence from Firm-Level Data. In World Economy, 30(1), 60-82.

Zubarevich, N. (2015). Regional Dimension of the New Russian Crisis. In Social Sciences, 46(4), 3-18.

\title{
Теоретические и прикладные аспекты оценки конкурентоспособности лесной промышленности
}

\author{
Р.В. Гордеев \\ Сибирский федеральньй университет \\ Российская Федерачия, Красноярск \\ Институт экономики \\ и организации промышленного производства СО РАН \\ Российская Федерачия, Новосибирск
}

\begin{abstract}
Аннотация. В отечественной и зарубежной литературе большое внимание уделяется вопросам конкурентоспособности стран, отраслей, регионов. Однако сегодня не существует универсальной меры ее оценки. В настоящей работе анализируются теоретические и прикладные аспекты проблемы конкурентоспособности с точки зрения двух основных подходов: сравнительных преимуществ, берущих свое начало в теории международной торговли, и конкурентных преимуществ, традиционно ассоциирующихся с теорией М. Портера. Дан анализ современных прикладных исследований, посвященных тематике конкурентоспособности продукции лесопромышленного комплекса. Показано, что наиболее часто для решения данной задачи используют следующие методы: расчет выявленных сравнительных преимуществ; оценку индексов цен на лесопромышленную продукцию; анализ постоянной доли рынка; построение оптимизационных моделей; анализ различных отраслевых показателей. Проанализированы плюсы и минусы подхода выявленных сравнительных преимуществ в торговле как наиболее удобного для оценки конкурентоспособности отечественного лесного комплекса.
\end{abstract}

Ключевые слова: конкурентоспособность, сравнительные преимущества, конкурентные преимущества, теории международной торговли, лесной комплекс.

Исследование выполнено при финансовой поддержке РФФИ в рамках научного проекта № 18-010-01175.

Научная специальность: 08.00.05 - экономика и управление народным хозяйством. 